Socialist Studies / Études socialistes 7(1/2) Spring/Fall 2011: 141-170

Copyright (C) 2011 The Author(s)

SPECIAL ISSUE ON ORGANIZING FOR AUSTERITY: THE NEOLIBERAL STATE, REGULATING LABOUR AND WORKING CLASS RESISTANCE

\title{
Austerity, Competitiveness and Neoliberalism Redux Ontario Responds to the Great Recession
}

\section{CARLO FANELLI and MARK P. THOMAS}

Sociology \& Anthropology, Carleton University. Toronto, Ontario, Canada. Sociology, York University. Toronto, Ontario, Canada.

\begin{abstract}
This article examines the deepening integration of market imperatives throughout the province of Ontario. We do this by, first, examining neoliberalism's theoretical underpinnings, second, reviewing Ontario's historical context, and third, scrutinizing the Open Ontario Plan, with a focus on proposed changes to employment standards legislation. We argue that contrary to claims of shared restraint and the pressing need for public austerity, Premier McGuinty's Liberal's have re-branded and re-packaged core neoliberal policies in such a manner that costs are socialized and profits privatized, thereby intensifying class polarization along with its racialized and gendered diversities.

\section{Résumé}

Cet article analyse l'intégration de plus en plus profonde des impératifs du marché dans la province de l'Ontario. Nous faisons cette analyse, premièrement, en analysant les bases théoriques du néolibéralisme, deuxièmement, en décrivant le contexte historique de l'Ontario, et troisièmement, en examinant le "Open Ontario Plan", sous l'angle particulier des propositions de changement de la législation sur le droit du
\end{abstract}

\begin{abstract}
Carlo Fanelli is a PhD candidate in the Department of Sociology \& Anthropology at Carleton University. He is Coordinating Editor of Alternate Routes: A Journal of Critical Social Research and co-editor of Capitalism \& Confrontation: Critical Perspectives (forthcoming 2011, Red Quill Books). Mark Thomas is Associate Professor in the Department of Sociology at York University (Toronto, Canada). His research interests are in the areas of political economy and economic sociology, with a primary research focus on the regulation of labour standards at local, national, and transnational scales. He is the author of Regulating Flexibility: The Political Economy of Employment Standards (2009, McGill-Queens), co-editor (with N. Pupo) of Interrogating the New Economy: Restructuring Work in the $21^{\text {st }}$ Century (2010, University of Toronto Press) and co-editor (with D. Brock and R. Raby) of Power and Everyday Practices (forthcoming 2011, Nelson). His most recent project, titled "From Labour Rights to Human Rights: Emerging Approaches to Labour Standards in the Global Economy", examines the economic, political and social factors that shape the regulation of transnational labour standards.
\end{abstract}

Carlo Fanelli est doctorant dans le département de sociologie et anthropologie à I'Université de Carleton. II est la coordinateur de la revue Alternate Routes: A Journal of Critical Social Research et co-rédacteur du livre Capitalism \& Confrontation: Critical Perspectives (à paraître en 2011, Red Quill Books). Mark Thomas est professeur associé dans le département de sociologie à l'université de York (Toronto, Canada). Ses centres de recherches sont dans les domaines de l'économie politique et la sociologie économique, avec un intérêt particulier pour la régulation du droit du travail aux niveaux local, national et transnational. II est l'auteur de Regulating Flexibility: The Political Economy of Employment Standards (2009, McGill-Queens), co-rédacteur d'Interrogating the New Economy: Restructuring Work in the $21^{\text {st }}$ Century (2010, University of Toronto Press) avec N. Pupo et co-rédacteur de Power and Everyday Practices (forthcoming 2011, Nelson) avec D. Brock et R. Raby. Son projet le plus récent, intitulé «Du droit du travail aux droits humains: des approches émergentes du droit du travail dans l'économie globale ", analyse les facteurs économiques, politiques et sociaux qui façonnent la régulation du droit du travail transnational.

Socialist Studies / Études socialistes: The Journal of the Society for Socialist Studies / Revue de la Société d'études socialistes www.socialiststudies.com 
Socialist Studies / Études socialistes 7(1/2) Spring/Fall 2011: 141-170

travail. Nous soutenons que sous le couvert de discours prônant le partage de l'austérité et l'impérieuse nécessité de restreindre les dépenses publiques, les Libéraux du Premier McGuinty ont ré-étiqueté et reformulé les politiques néolibérales de façon que les coûts soient socialisés et les profits privatisés, aggravant ainsi la polarisation des classes ainsi que les inégalités liées à la race et au genre.

\section{Keywords}

austerity; employment standards; neoliberalism; Open Ontario Plan

Mots-clés

austerité; néoliberalisme; Open Ontario Plan; droit du travail

In the midst of transition from rescue to recovery from the Global Financial Meltdown, states around the world have responded with exceptional austerity measures. This round of austerity has been dynamic and multidimensional throughout North America and Europe (Panitch et al. 2010; Fanelli et al. 2010). Rather than being dislodged, neoliberalism as a political-economic project seems to be gaining renewed momentum the world over amid capitalist militancy and the absence of broad-based and sustained resistance. Indeed, financial crises and recessions actually serve an operational purpose in capitalism, despite the instability and devastation wrought. Not only do intermittent crises discourage investors from escalating risks in pursuit of maximizing profits, but financial volatility actually reinforces and intensifies competitive pressures among and between firms and workers, thereby heightening market dependence and rehabilitating the conditions for renewed accumulation.

In what follows, we focus on the recent trajectory of neoliberal policy responses in Ontario. First, we illustrate the connections between the broader neoliberal political project that was initiated by the capitalist class in the 1970s and present-day austerity measures. We then outline the transition to neoliberalism in Ontario, tracing this evolution beginning with Bob Rae's NDP government in the early 1990s, through the years of the Mike Harris' Conservatives, to Dalton McGuinty's Liberal government. Third, we present an analysis of the austerity programmes set in motion by McGuinty's government since the onset of the recession through an overview of both the Open Ontario Plan (OOP) and the Open for Business Act (OBA), legislation introduced in May 2010 to promote "economic competitiveness" in the province. In spite of claims that we are living in radically different times and that we must collectively share the costs, the provincial government has re-branded and re-packaged neoliberal policies 
FANELLI and THOMAS: Austerity, Competitiveness, and Neoliberalism Redux

in such a manner that costs are socialized and profits privatized. We argue that, contrary to claims of shared restraint and austerity, the measures advanced by the government of Ontario heighten class polarization during this period of the current crisis.

\section{Neoliberalism and New Spaces of Accumulation}

Neoliberalism as both political philosophy and social policy developed in the context of the capitalist economic downturn that began in the early 1970s. This downturn led to wide-ranging transformations in the social organization of work, labour relations, and labour market policies.

Neoliberalism emerged in this conjuncture as a challenge to Keynesianism and as a prescription for a return to capitalist profitability (Harvey 2006; Jessop 1993). Specific neoliberal strategies include social policy oriented towards fiscal restraint, trade policies designed to promote competitiveness and capital mobility, and labour relations that promote the individualization of economic risks.

Proponents of neoliberalism claim that the model is premised on the idea of reducing the role of the state in regulating the economy, as if removing "the state" from the equation will enhance competitive economic relationships and lead to "perfect equilibrium" (Perelman 2006). However, this naturalized view of the market neglects the central role played by state agencies in establishing institutional preconditions for private property, free markets and free trade, and capital accumulation in general (Wood 2005). Thus, despite neoliberal assertions of the need for markets free from government regulation, neoliberalism relies quite clearly on the role of the state to regulate the economy, as the implementation of the neoliberal model has produced social and economic policies that are overtly oriented towards advancing the interests of capital (Block 2002; Harvey 2006). These include: the deregulation of foreign direct investment, liberalizing trade and financial services; setting the conditions for more "flexible" employment and serving injunctions on unions when contract negotiations go awry; offering subsidies and incentives for new productive facilities or leasing out public lands for resource extraction at discounted prices; workfare in place of welfare; personal and corporate tax reductions in order to stimulate consumption; and a shift away from universal social programs to market-based models (Peck 2001, 2005; Harvey 2005; Brenner 1999). Thus, while in principle neoliberalism identifies the absence of state regulation as a strategy for economic prosperity, in practice neoliberalism has resulted in the re-orientation of social policies 
and state intervention in the economy in ways that support capitalist profitability.

Moreover, neoliberal governments have played an essential role in reconfiguring territories to facilitate expanded opportunities for investment free from the costs of social and physical infrastructure. This has entailed a shift from the administrative structures of the Keynesian welfare state that sought to alleviate interregional inequalities through redistributive policies, to growth-oriented strategies that encourage economic development by pitting regions against one another for competitive access to trade, goods, resources and services (Brenner 1999; Harvey 2006).

Neoliberalism, then, can be understood as a fluid, ongoing process rich in change that has entailed the rescaling of political administration through multi-level governance arrangements via shifting territorialities in order to attract capital investment (Brenner and Theodore 2002). This has entailed the concurrent introduction of new state supports and mechanisms that facilitate private accumulation, in addition to the retrenchment of social protectionisms provided by the state, and the simultaneous devolution and upwards transference of regulatory responsibilities, most often without matching fiscal tools or regulatory decision making powers, to other governments (McBride and Shields 1997; Peck 2005). All this can be understood as the competitive re-regulation of neoliberalism within and between multi-level governments, or the locking in of inter-jurisdictional competition, with the aim being to ensure sustainable accumulation. ${ }^{1}$ In addition, central to the core recipe of neoliberalism is the movement away from government-led entitlement programs towards an increasing reliance on private charity through faithbased interventions, philanthropy and volunteerism, assertions expounding the virtues of entrepreneurialism and individualism, relentless street-level policing of public disorder and a fidelity to private sector-led development (Peck 2006).

In addition to the class dynamics of neoliberalism indicated above, feminist political economists have identified gendered dimensions of neoliberal policies (Bezanson and Luxton 2006; McKeen and Porter 2003; Jenson et al. 2003). For example, neoliberal policies have promoted the

1 This also serves the purpose of preventing progressive governments from using their regulatory authority to erect trade barriers against the goods and services from other political units, thereby entrenching capital mobility and avoiding any centralization or harmonization of market-inhibiting policies (Harmes 2006). 
FANELLI and THOMAS: Austerity, Competitiveness, and Neoliberalism Redux

privatization of social services and the lack of support for child care, which, in the context of persisting gendered divisions of labour, have increased the demands on women's responsibilities in the home. Neoliberal policies have also reproduced patterns of gendered labour market inequality through transformations in income security policies that are premised on the male income earner model of paid employment. This dynamic serves to further individuate responsibility by ignoring how complex socio-historical structural relations constrain the space for choice and subjectivity. A key aspect of neoliberalism is the increased individualization of economic risk, whereby neoliberal subjects are constituted through economic and political processes that promote the commodification of all aspects of social life, including relations of social reproduction (Braedley and Luxton 2010). This is especially pertinent to women in the public sphere as it has been here where they have made the most gains and labour market segmentation less pronounced, as compared with their private-sector counterparts (Boyd 1997; Armstrong et al. 2001). All in all, the intrusion of neoliberal market mechanisms into public services and industries represents a frontier opportunity to harmonize downwards the quality, pay and working conditions of the public-sector with the private sphere. ${ }^{2}$

Neoliberalism has individualized economic risks, leading to a growing precariousness of job tenure as well as heightened stress and work-life conflicts owing to long hours of work and lack of control over working time (Thomas 2009; Lewchuk et al. 2011). More specifically, neoliberal labour market policies tend to further expose labour to market forces, in particular the pressures of commodification. In this neoliberal context, labour legislation and labour market policies are often designed to "weaken protective regulations, restrict collective institutions and strengthen pro-individualistic regulations" (Standing 1999, 42). As such, longstanding patterns of labour market inequalities are exacerbated, with disproportionate effects on already marginalized groups. For example, patterns of racialized labour market inequality in Canada intensified as neoliberalism weakened labour market protections and income security policies (Creese 2007; Galabuzi 2006; Jackson 2009; Teelucksingh and Galabuzi 2005; Thomas 2010). Racialized groups are disproportionately represented in low-income occupations across the labour market and these employment patterns are reflected in overall employment earnings

\footnotetext{
${ }^{2}$ Although the foregoing analysis emphasizes the legislative and public policy responses of the Ontario government, there effects are not gender or racially neutral. Unfortunately, however, a detailed exegesis of these concerns is beyond the scope of this paper.
} 
for racialized group members that are below the Canadian average, with racialized families two to four times more likely to fall below low-income cutoff measures (Colour of Poverty 2007). Further, new immigrants are more than twice as likely as Canadian-born to experience chronic low incomes (ibid). These employment and earning differentials have contributed to a broader racialization of poverty, where racialized groups are more likely than non-racialized groups to have overall earnings below the poverty line (ibid). Overall, then, as public policy became increasingly neoliberalized this has brought about increases in labour market insecurity, which have disproportionately affected racialized groups. ${ }^{3}$

Likewise, the erosion of income security policies and labour market protections has contributed to growing economic polarization in Canada over the past several decades (Naiman 2008; Yalnizyan 1998, 2010). For example, in the 1970s, the wealthiest ten percent of the population received 23 percent of total market income. This increased to 28 percent by the 1980s and 37 percent by the 1990s. By 1999, the wealthiest ten percent of families held 53 percent of the wealth in the country. Furthermore, between 1970 and 1999, their average wealth increased by 122 percent; while the poorest ten percent saw their debts increase by 28 percent. In 2009, income disparities had reached levels unseen since the 1920s (Yalnizyan 2010, 3-4). Canada's richest one percent took home 32 percent of all growth in incomes from 1997-2007. Similarly, while in the $1950 / 60$ s the income share taken by the top one percent of earners was less than eight percent, by 2007 this had reached 13.8 percent. A significant contributing factor has been the continuing regressive overhaul of the Canadian tax system. While in 1948 the top marginal tax rate for income earners making $\$ 250,000$ (\$2.37 million in today's dollars) was 80 percent, the top tax rate in 2009 averaged across Canada was 42.9 percent for income above $\$ 126,264$. By 2009 , these measures contributed to 3.8 percent of Canadian households controlling $\$ 1.78$ trillion in financial wealth, or 67 percent of the Canadian total (ibid). With the onset of the Great Recession, these historical trends have undergone a swift intensification. In what follows, we trace the evolution of neoliberalism in Ontario with an emphasis on the Premiership of Dalton McGuinty.

${ }^{3}$ A more complete analysis of the racialized dimensions of neoliberalism and austerity measures is beyond the scope of this paper. For a discussion of the racialized implications of the Open for Business Act see Gellatly et al. (2011). 
FANELLI and THOMAS: Austerity, Competitiveness, and Neoliberalism Redux

\section{From Rae to Harris to McGuinty}

Ontario has historically been a province dominated by Progressive Conservative (PC) rule. Unbeaten from 1943 to 1985, Ontario's "natural" governing party is distinguished by its affinity to "red Toryism", which was particularly true under former Premier Bill Davis who led the party from 1971 to 1985.4 The year 1985 is enigmatic of a paradigm shift; that is, the culmination of a preceding decade of transition in Ontario politics, whereby neoliberal policies came to dominate political discourse. This drift toward the political and economic right, whereby neoliberalism would become the new orthodoxy, ushered in a tumultuous time in Ontario's political affairs. The short-lived tenure of former Liberal Premier David Paterson, who governed from 1985 to 1990, witnessed the simultaneous rightward movement of both the provincial Conservatives and the New Democratic Party (NDP).

This rightward shift in the province is evident through several successive governments, beginning in an early form with the social democratic NDP government of Premier Bob Rae, and taking its sharpest turn throughout the 1990s with the PC government of Premier Mike Harris. We suggest that, while distinct from the Harris years, the Liberal government of Dalton McGuinty has also adopted neoliberal principles in its social and economic polices, particularly through austerity measures in the aftermath of the Great Recession. Rather than cast neoliberalism as a monolithic policy prescription, however, we outline varieties of neoliberal strategies through these three governments, and place greatest focus on its most recent form through McGuinty's $O B A$.

Elected in 1990, the NDP's Bob Rae ran on a progressive program emphasizing investments in social services, education, health care, infrastructure and changes to employment standards legislation. Rae's NDP enacted significant changes to Ontario labour laws through Bill 40, such as the combining of bargaining units of an employer and the same trade union, imposing strict time-limits on arbitration decisions, introducing successor rights, restricting the use of replacement workers and introducing a wage protection program for workers when employers

${ }^{4}$ Basic tenets of red Toryism include modest investments in physical infrastructure, limited welfare state provisions and a role for government in nurturing industry and commerce. This is differentiated from "blue Toryism", which is often fused with socio-cultural and religious conservatism, including a steadfast conviction to neoclassical economic theory and an avid emphasis on reducing the public spheres role in the economy through privatization, reductions in taxes and corporate welfare (MacDermid and Albo 2000; Brooks 2009). 
go bankrupt. The NDP government also proposed increases on business taxes and efforts to strengthen environmental and equity rights. But the NDP's time in office was marred by its own shift towards anti-labour politics towards the end of its term. High levels of business opposition to Rae's government, combined with the NDP's adoption of deficit reduction and balanced budgets as a means of resolving economic problems, including the notorious reopening of labour contracts and an imposed "social contract" on public sector workers, marred the NDP's term in power and tainted relations with organized labour (Panitch and Swartz 2003). ${ }^{5}$

Business opposition to the social democratic government, the growing credence of neoliberal policies, and the fragmentation with the Left laid the foundation for the PCs to ride the tide of populist uncertainty and escalating economic insecurity amidst the deep recession of the early 1990s. Elected in 1995, Harris' platform signaled the integration of neoliberal orthodoxy along simple, straightforward and easily conveyed messages - tax cuts, less government, welfare reform and enhanced business investment - all captured under the party's platform slogan "Common Sense". Upon coming to power, the Harris government worked diligently to undo a number of progressive changes enacted during the tumultuous tenure of Bob Rae's New Democratic Party (NDP) government. They established the Red Tape Review Commission, whose aim was to eliminate policies that impeded competitiveness or placed "inappropriate regulatory measures" on businesses. The PC's also introduced Bill 7, which repealed the amendments to the Ontario Labour Relations Act introduced by the NDP through Bill 40 and reformed union certification procedures. This included substantially rewriting Ontario's labour and employment laws in order to make the province "open for business" by replacing automatic certification following card signing with an election model using secret ballots, eliminating the prohibition of replacement workers during strikes, reducing the threshold to trigger decertification, and repealing the rights of agricultural and domestic workers' to unionize. In the years following Bill 7, the PC's introduced a series of changes to Ontario's

\footnotetext{
${ }^{5}$ The dynamic reach of capital obstructed the NDP at every move to the point where, despite capitulating to business interests, the organized and collective class-war from above sealed the NDP's fate in Ontario (Walkom 2002; Kaplan 2010). This is also demonstrative of the continuing theoretical and concrete challenges plaguing "third way" social democracy as capital was unwilling to renege on the crumbling class compromise that had characterized the post-War years.
} 
FANELLI and THOMAS: Austerity, Competitiveness, and Neoliberalism Redux

Employment Standards Act as well, which included the extension of the work week to 60 hours, four-week averaging of overtime, and freezing the minimum wage at $\$ 6.85$ for nine years (Kozolanka 2007; Thomas 2009; Workman 2009).

The PCs' tenure from 1995 to 2003 radically reoriented the province along the lines of neoliberalism. In response, this led to the Days of Action movement throughout Ontario that mobilized labour and community groups in opposition to the ever-increasing penetration of Harris' neoliberal program. Despite the deepening reality of class polarization, however, internal fractures among the Days of Action participants, such as that between more moderate and radical labour unions, and tensions among community groups and anti-capitalist activists, stymied its progression into an alternative political project and led to its eventual demise (Leach 2002; Goldfield and Palmer 2007).

Dalton McGuinty's Liberals were elected to the Ontario legislature in 2003 amid a torrent of backlash directed at the governing PC's. McGuinty, who had first been elected as a Liberal Member of Provincial Parliament (MPP) in 1990 and was elected party leader in 1996, ran on a platform that prioritized public sector healthcare and education, environmental protection and a tax freeze. Amid mounting backlash against the Conservative government, especially around the shooting death of native protestor Dudley George at Ipperwash and the tainted water scandal in Walkerton, McGuinty was able to position himself as a "moderate", becoming Premier of Ontario in 2003 and gaining a Liberal majority. Centrist/progressive intimations notwithstanding, McGuinty prioritized as his first task the tackling of the $\$ 5.6$ billion deficit inherited from the PCs, indicating that his underlying orientations were in fact neoliberal. Despite modest investments in health and elder care, education, municipal transfers and social assistance, as well as annual increases to the minimum wage, these improvements still failed to repair/counteract the significant cuts enacted by Harris. In fact, McGuinty's tenure has been wrought with rescinded promises that quietly consolidated and extended the earlier core of Harris' project. These include the privatization of services formerly covered under the Ontario Health Insurance Plan, such as eye examinations and physical rehabilitation, the imposition of a staggered health premium ranging between $\$ 60$ and $\$ 900$ per year, reneging his campaign promise to close all coal-powered plants by 2007 , and the weakening of the Environmental Assessment Act in order to 
exempt the Liberals' energy plan from review. ${ }^{6}$ In key ways, then, this can be seen as the adaptation of a neoliberal orientation, though in a less overt form than Harris, by a government that took power by positioning itself through centrist politics.

Elected to a second mandate in 2007, McGuinty's campaign benefited from PC leader John Tory's highly controversial plan to extend public funding to faith-based schools. The NDP failed to galvanize public support with a platform premised on holding the line on MPP pay, tax breaks for the "everyday" worker and modest investments in public services. Absent was any notion of its earlier proposals for public auto insurance, wealth and inheritance taxes, or any fundamental challenge to big business or the neoliberal paradigm. ${ }^{7}$ McGuinty's 2007 election marked the first time in 70 years that the Liberals have been able to secure back-toback victories in Ontario since 1937, despite the all-time lowest voter turnout (CBC News 2007a/b). ${ }^{8}$ All things considered, the 2007 election revealed the public's growing apathy for electoral politics, as well as disconnect between those striving for electoral reform and the general populace.

In the summer of 2007, what would generally become known as the Great Recession was quickly spreading throughout the globe. Initially centered in the US "sub-prime" housing market, a cascading liquidity crisis ravaged property markets as the exotic financial instruments meant to safeguard risk were increasingly showing themselves to be "toxic", that is, valueless. As bank failures spread throughout the US and Western Europe, including the pre-emptive bailout of Canadian banks by Prime Minister Stephen Harper's Conservatives, it was increasingly becoming clear that the current recession was unmatched in severity and scope since the Great Depression of the 1930s (Evans and Albo 2010; Fanelli and Hurl 2010; Panitch et al. 2010). With the war against inflation more or less stable in the preceding decade, corporate and personal taxes at all time lows and

\footnotetext{
${ }^{6}$ In particular, see Ontario budgets 2004-2007.

${ }^{7}$ Of importance also was the growing influence and higher polling of the Green Party, though any expectations of a more radical platform has subsequently been tempered given the party's fidelity to an eco-capitalist platform that mirrors many of the Liberal party's proposals, though in environmental rhetoric (Zimmerman 2009). .

${ }^{8}$ Of special importance, too, was the historic referendum on whether to move from a firstpast-the-post to mixed member proportional representation electoral system. Amid exceptional public confusion, right-wing propaganda and lack of popular understanding, the measure failed with only 37 percent of the vote in favour (Howlett, 2007; Fenlon 2007; CBC News 2007c).
} 
FANELLI and THOMAS: Austerity, Competitiveness, and Neoliberalism Redux

corporate profits nearing the highs of the 1960s, neoliberalism suffered its biggest ideological blow when, in light of the crisis, its leading guru Alan Greenspan admitted he had put "too much faith in the self-correcting power of free markets and had failed to anticipate the self-destructive power of wanton mortgage lending" (Andrews 2008), thereby raising the prospect of a possible return to Keynesian oriented social and economic policies. Despite the admission of "moral hazard" and the widespread declarations of neoliberalism's impending demise, however, the Global Financial Meltdown has thus far shown itself to be little more than a temporary legitimacy crisis. In fact, contrary to the return of Keynesianism (Fernandez 2009), neoliberalism has re-emerged hardened and emboldened in a revitalized form.

Throughout McGuinty's terms, he has shown himself to be a much more sophisticated and nuanced neoliberal than his predecessors. By reversing some (but not all) of the labour market reforms made by Harris, introducing new public management techniques in health care via P3s to build hospitals and the introduction of Local Health Integrated Networks to rationalize the health system along market pressures, including a focus on supply-side labour market responses to unemployment through Second Career/retraining (Armstrong 2001; Loxley 2010), McGuinty's Liberals have shown themselves much more comfortable veering between stringent neoliberal orthodoxy and political opportunism. For instance, McGuinty's political brinkmanship includes counter-measures such as the raising of the minimum wage over several years after taking power ${ }^{9}$ and investments in the automotive industry. Despite some modest "pump-priming", most visible in the short-term stimulus of $\$ 4.6$ billion for infrastructure and $\$ 2.2$ billion for post-secondary funding, as well as the $\$ 3.5$ billion bailout of General Motors, these measures have been matched by tax shifting for competitiveness, wage repression, and the streamlining of public sector services (Ontario 2009, 2010). As the transition from "rescue strategies" to "exit strategies" turns sharply, Ontario provides a vivid portrait of the ongoing metamorphoses of core neoliberal policies.

\footnotetext{
${ }^{9}$ In the course of writing, the raising of the minimum wage was subsequently frozen at $\$ 10.25$. McGuinty justified this act by citing the need to help "employers", as opposed to employees, "get back on their feet". Despite billions of dollars in corporate welfare amid rising food, housing and energy costs, minimum wage earners are expected to shoulder the brunt of socalled restraint measures (n.a. Toronto Star 2011).
} 


\section{Responding to the Crisis: The Open Ontario Plan (OOP)}

The government clearly signaled its intention to embrace neoliberal austerity measures in Finance Minister Dwight Duncan's budget speech on 8 March 2010, during which he introduced the OOP (Ontario 2010a). In both name and policies, the Plan signaled a new era of austerity in the course of reorganizing neoliberalism to reassert its legitimacy as both political philosophy and policy orientation. In seeking to reestablish the ideological legitimacy of neoliberalism and, therewith, ensure that the brunt of bailing out capitalism (and neoliberalism) is borne by the working class, the Ontario government is integrating aspects of both deregulation and austerity. In May 2010, the government introduced the $O B A$ as a key component of this plan. The $O B A$ was part of a much larger government initiative to create a climate favorable for business in the province, with the government claiming it would do this while simultaneously protecting the environment and the broader public interest (Ontario Ministry of Labour 2010a). The wide ranging Act, with over 100 proposed amendments to various pieces of legislation, included provisions to establish a "modern, risk-based" approach to environmental approvals, as well as new procedures to enable "efficient resolution" of employment standards claims. The Act also included amendments to facilitate easier access for some foreign trained professionals to employment in Ontario. The government framed the $O B A$ as legislation that would promote new and transparent relationships between business and government, while also providing protections in areas such as environment and employment. Sandra Pupatello, Ontario Minister of Economic Development and Trade, described the Act as follows:

Our government is committed to helping businesses focus on what they do best - creating jobs for Ontario families. We can protect the public interest without creating unnecessary barriers to business. The $O B A$ will save businesses both time and money (Ontario Ministry of Labour 2010a).

Clearly, the articulation suggested here implies that "modern" government ought to enhance (rather than impede) "competitiveness", while the seemingly neutral chimera of "prosperity" obscures the class dimensions of the public interest. Interestingly, the frame of "modernization" is not new; it was a catchword of Harris-era employment standards reforms as well, when Harris' government "modernized" employment standards by introducing a 60-hour work week, freezing the minimum wage, and 
FANELLI and THOMAS: Austerity, Competitiveness, and Neoliberalism Redux

allowing for the averaging of overtime hours so as to undermine overtime premium rates (Thomas 2009).

Ontario's business community was clearly in favor of the kinds of deregulatory measures found in the $O B A \cdot{ }^{10}$ For example, Len Crispino, President \& CEO of the Ontario Chamber of Commerce, claimed:

Concrete measures to reduce red tape in Ontario are long overdue, particularly in the areas of labour and environment. Improvements will allow our members to spend more of their money advancing productivity and creating jobs, both of which are vitally important for Ontario's prosperity, rather than dealing with onerous and sometimes contradictory regulations (Ontario Ministry of Labour 2010a).

The 00P emphasizes five central courses of action: (1) tax relief; (2) a wage freeze for public sector employees; (3) privatization of public assets; (4) the development of "innovation corridors" to promote inter-provincial trade; and (5) reforms to "modernize" employment standards legislation. First, like the federal Conservatives, the government of Ontario lowered the general Corporate Income Tax (CIT) rate from 14 percent to 12 percent and it will be further reduced to 10 percent by 2013-14. This also included the lowering of the CIT for manufacturing and processing from 12 percent to 10 percent, while small businesses saw the CIT cut from 5.5 percent to 4.5 percent and the small-business deduction surtax eliminated. This will make Ontario's CIT among the lowest in the OECD. The Corporate Minimum Tax was reduced from 4 percent to 2.7 percent in 2010, with more small and medium-sized businesses now made exempt. Likewise, the Capital Tax has been completely eliminated. ${ }^{11}$ Following suit, personal

\footnotetext{
${ }^{10}$ Similarly, Elyse Allan, President and CEO of General Electric Canada, offered the following: "I applaud the government's move to reduce business costs by streamlining regulations and harmonizing them with other jurisdictions where possible. The reforms in the procedure for environmental Certificates of Approval, for example, could bring significant benefits to GE and other companies. With regulatory simplification and recent changes in the tax structure, the Ontario government has taken important steps to make Ontario an attractive place for companies to invest and create jobs" (Ontario Ministry of Labour 2010b).

${ }^{11}$ This was a small surcharge of 0.3 percent on the first $\$ 400$ million of taxable capital, 0.54 percent for non-deposit taking financial institutions with taxable capital over $\$ 400$ million and 0.67 percent on deposit taking financial institutions with over $\$ 400,000$ million in taxable capital. This translates into a $\$ 500,000$ million per year subvention for companies like Rogers, Thompson-Reuters, Manulife, Royal Bank, Suncor and their kinfolk.
} 
income tax cuts have also been enacted. ${ }^{12}$ All in all, following the full phasein of Ontario's comprehensive tax reforms, the marginal effective tax rate, which measures the tax burden on new business investment, will be cut in half by 2018. As such, businesses will be subsidized by $\$ 4.6$-billion from tax cuts on income and capital over the next three years under the guise of stimulating "competitiveness" and attracting investment. ${ }^{13}$ However, while personal income tax cuts have a broad populist appeal, especially given large personal debt loads and rising consumer prices, ${ }^{14}$ such corporate giveaways and tax reductions have been shown to have a negligible impact on job creation (Whittington and Delacourt 2011).

Second, on 25 March 2010 the Ontario government enacted the Public Sector Compensation To Protect Public Services Act. Affecting roughly 16 percent of Ontario's workforce, the Act imposes a two-year wage freeze for 350,000 non-unionized public sector workers, while also indirectly affecting 710,000 unionized public sector workers that are being asked to take a "voluntary" two-year wage freeze. Premier McGuinty and Finance Minister Duncan have forcefully insisted that their government will not fund net compensation increases to operational costs associated with collective agreements, thereby indirectly stifling free collective bargaining. ${ }^{15}$ Both McGuinty and Duncan have consistently reiterated that they are not ruling anything out when it comes to legislating austerity, wage freezes or furloughs (Ferguson and Benzie 2009). Such measures will allegedly "save" the government $\$ 750$ million over two years. Equally important, McGuinty has urged Ontario municipalities to follow their lead

\footnotetext{
${ }^{12}$ For instance, the tax rate on the first $\$ 37,106$ of taxable income has been reduced by 16.5 percent, from 6.05 percent to 5.05 percent, while those earning up to $\$ 80,000$ per year saw a tax cut of 10 percent.

${ }^{13}$ Meanwhile, nearly $\$ 1$ billion will be lost by the government owing to cost overruns at public-private-partnerships and the introduction of privatization measures (OMF 2010a/b; OPSEU, n.d.).

${ }^{14}$ In Ontario, the Consumer Price Index rose 2.9 percent in the 12 months to January 2011, after advancing 3.3 percent in December 2010, with the highest increases coming in fuel, food, footwear, clothing and personal vehicle insurance (Statistics Canada 2011

${ }^{15}$ Of positive note here is the arbitration decision by Norm Jesin awarding 17,000 workers in long-term care homes a 2 percent wage increase for 2010. In his ruling, Arbitrator Jesin said that employers and labour leaders must respond to economic decisions, not a government's fiscal policy, in setting wages (Benzie and Ferguson 2010). In a similar ruling, Arbitrator Martin Teplitsky, defying the Liberal's proposed wage freeze, awarded University of Toronto faculty and librarians a 4.5 percent wage increase over two years. Refusing to appear a "minion of government" and "compromise my independence", Teplitsky noted his ruling echoes average private sector wage hikes at 2.3 percent over the year in Ontario (Brown 2010).
} 
FANELLI and THOMAS: Austerity, Competitiveness, and Neoliberalism Redux

and impose a five percent cut in expenditure growth while freezing wages, warning that he could have "imposed" this on cities (Benzie and Maloney 2010). In suggesting that Ontario's 139,000 municipal workers make a "sacrifice", opportunistic mayors and councilors throughout Ontario have been squeezing the austerity vice-grip (most visible in the policies of Toronto's newest mayor, Rob Ford).

Nevertheless, the Ontario Ministry of Finance, echoing McGuinty and Duncan, reiterates the need for "everyone who is paid through taxpayer dollars to do their part" (Ontario Ministry of Finance 2011). But, of course, not only does compensation restraint not extend to the private sector, it excludes those most generously remunerated by public tax dollars. The restraint measures exclude public sector managers and CEOs who are still entitled to "performance-related" pay and bonuses. This means, for instance, that CEOs in public sector organizations are not included, such as University Health Network CEO Robert Bell (paid just under \$831,000 per year) and OMERS CEO Michael Nobrega (at about \$1.9-million per annum), and neither are corporations heavily dependent upon public sector contracts, such as P3s, or for-profit companies like Extendicare and its CEO Tim Lukenda (at \$1.5-million in yearly total compensation). The restraint act targets workers earning between fifty and twenty-five times less and particularly impacts women in the public sector due to gendered pay differentials (SEIU 2010). Moreover, average public sector wages in Ontario did not return to their real 1992 levels until 2008, an improvement this restraint act undermines by freezing pay and thereby restarting a dynamic that will once again contribute to the deterioration of public sector wages.

Third, the Ontario government is contemplating the massive privatization of public goods and assets in order to pay down its deficit (Benzie 2010). McGuinty's Liberals recently paid \$200,000 to CIBC World Markets and Goldman Sachs to create a white paper proposing the creation of "SuperCorp". The idea behind the mega-corporation would be to combine Ontario's Crown assets, including nuclear power plants, power generation facilities, 29,000 kilometers of electrical transmission and distribution lines, six-hundred plus liquor stores and gaming operations, in order to package and sell it off bit by bit. By ceding "fiduciary control", the government alleges the $\$ 60$ billion could be put to better use by private investors, meanwhile serving the public's interest by paying down the debt. One-time fiscal injections, however, are hardly a remedy for chronic under-funding and systemic undermining. In the meantime, though, it seems that the selling of Crown assets has been shelved in order to deal 
with the politically sensitive task of wage freezes and the shrinking of the public sector as a whole.

Fourth, the provincial government is engaged in the development of "innovation corridors" to promote inter-provincial trade and investment. The Ontario-Quebec Trade and Cooperation Agreement signed between the provinces on 11 September 2009, which extends previous agreements, is "designed to increase investment and trade between Ontario and Quebec, promote innovation and reduce long-standing barriers to business" (Economic Development and Trade 2011; Quebec-Ontario Trade and Cooperation Agreement 2009). As the fourth largest economic zone in North America, the explicit aim is to create a common economic space, including "precedent-setting" chapters on financial services, energy, transportation and regulatory cooperation, in order to compete against the next largest geo-economic zones (New York, California and Texas) and rising opponents (e.g. the Maritimes and western provinces). With a combined Gross Domestic Product of over $\$ 800,000$ billion in 2007 , and cross-border trade valued at over $\$ 70$ billion in 2004 , the Agreement is unambiguous in its efforts to "liberalize trade and...enhance economic integration." Furthermore, the Ontario-Quebec Continental Gateway and Trade Corridor strategy aims to focus on the development of the region's high-technology, infrastructure, agriculture and manufacturing industries, as well as tourism and multimodal transportation systems that aim to improve the flow of exports to the US and other trade partners. Central to this Agreement is the push for further opening and integrating markets, increasing labour productivity and enhancing competition between and within jurisdictions. Moreover, like the North American Free Trade Agreement and the Canada-European Union Comprehensive Economic and Trade Agreement (currently under negotiation), the Ontario-Quebec agreement seeks to open up the public procurement of contracts by instituting a reciprocal non-discrimination clause that mandates the P3 route (Sinclair, 2010). Such an investor-state dispute mechanism, as is most blatantly visible with NAFTA's Chapter 11, essentially cedes democratic control and decision-making processes away from local communities and toward business interests that could sue any tier of government should they impinge upon their "right" to profit.

Finally, the $O B A$ contained a series of measures designed to "modernize" employment standards legislation in Ontario. As part of the 00P, Bill 68 replicates Alberta's and BC's "self-help" model for complaints and enforcement pertaining to the Ontario Employment Standards Act. Under the proposed changes, an employee would need to address the 
FANELLI and THOMAS: Austerity, Competitiveness, and Neoliberalism Redux

issues directly with their employer in advance of government intervention (Ontario 2010b). In turn, the employer must respond directly to the employee within a certain period of time. Should the employer fail to respond within a certain time frame, the Ministry of Labour would seek a response on behalf of the employee. In other words, employees are expected to make all "reasonable efforts" to resolve the dispute individually on a case-by-case basis. ${ }^{16}$ The Bill would mandate workers to first confront the employer before filing a complaint regarding owed backpay, wrongful dismissal, harassment, vacation and overtime. When the "self-help" system was introduced in BC in 2002, employment standards complaints from workers dropped 46 percent (ibid). While the government may attribute the drop in reports to improved dispute resolution mechanisms, given the extreme power imbalances in capitalist workplaces, a much more likely explanation is that the drop reflects the unwillingness of workers to confront their employer for fear of retribution.

The "modern" employment standards of the $O B A$ also place responsibility on individual workers to collect the information for their complaints and allowing Employment Standards Officers the ability to make decisions "on the best information available", thereby reducing expectations for a more rigorous and proactive inspections process (Ontario 2010c). If an officer determines that there is insufficient evidence provided by an employee, then the officer may determine there is no violation. Officers are also given a new role in negotiating a mediated settlement (Ontario 2010d). The implications of this amendment to the ESA are twofold. First, it promotes voluntarism by creating the potential for employers to resist the process if they feel it will not work in their favor. Second, it privileges a mediated settlement over an actual award, which may expedite the claims process but could reduce the value of the settlement achieved by a worker. Regardless of the outcome of individual settlements, this orientation represents a transformation in the role of ES officers from those who make judgments based on fact-finding to mediators in a process that assumes two equal parties, when in fact the parties are far from equal. ${ }^{17}$

${ }^{16}$ In a recent article in the Toronto Star, construction worker Raul Aguilera, describing his battle for unpaid wages against one of his former employers in BC, poses it thus: "How would you feel if you got robbed but couldn't report to the police unless you had first confronted the robber and asked for your money back?" (Keung 2010).

${ }^{17}$ In addition to the OBA, the Ministry of Labour struck an Employment Standards Task Force to address the backlog of 14,000 accumulated ES complaints and has given the Task Force a two-year mandate. The Task Force will investigate these claims through reviews of written 
According to the Ontario Ministry of Labour, the aim of ES modernization is to "establish services that achieve fairness for workers, while helping business to be increasingly competitive in the global economy" (Ontario 2010c). The assumption behind the changes to the employment standards complaints procedures is that "[m]ost employers want to do the right thing and they will often remedy the situation promptly and voluntarily, if they agree there is a valid claim" (Ontario 2010c). However, the new reforms to the ESA emphasize an individualized, privatized, and voluntary process for regulating ES complaints and settlements. Building on a decades-long legacy of ineffective employment standards regulation, the $O B A$ entrenched an individualized, complaintbased enforcement model that is likely to heighten conditions of labour market insecurity at a time of growing economic polarization.

All tings considered, the 00P forecasts seven years of austerity extending to 2017-18, when the budget will purportedly be balanced. Should this happen, as Evans and Albo (2010) show, this will result in a 20 percent contraction of Ontario's public sector economy (from 19.2 percent of GDP to 15.5 percent), thereby reducing the public sector's share to levels corresponding to the period of Harris' Common Sense Revolution. Perversely, these measures have not slowed representatives from the business community from arguing that Canada's labour laws are "too restrictive". ${ }^{18}$ This is a thinly veiled effort to restart talks aimed at undoing the Rand Formula, a definitive element of Canada's postwar settlement labour legislation. It is clear, therefore, that despite the temporary legitimacy crisis of neoliberalism, its most passionate proponents are emerging emboldened and on the offensive amid the lack of a sustained political fightback from labour.

evidence and telephone discussions, and in some cases in-person meetings (Ontario 2010d.). The new complaints procedures that place onus on complainants to provide evidence of ES violations will shape the process as "officers will make decisions on the available evidence" (ibid). Additionally, the Task Force will utilize the new emphasis on voluntary, mediated settlements as a means to resolve claims and to create a more efficient process (ibid).

18 Seizing a ripe political opportunity, Catherine Swift of the Canadian Federation of Independent Businesses used the week of Labour Day 2010 to argue, "When it comes to forcing workers to join a union and pay dues, Canada increasingly stands alone on this" (CFIB 2010). 
FANELLI and THOMAS: Austerity, Competitiveness, and Neoliberalism Redux

\section{Toward Recovery or Relapse?}

Contrary to economic recovery Canada and Ontario, paralleling international instabilities, are by no means out of the Great Recession. ${ }^{19}$ In fact, between October 2008 and October 2010, national unemployment remained at 7.8 percent, above the pre-recession rate of 6.2 percent but below its 2009 (8.7 percent) peak (CLC 2010; Grant 2011a). When considering discouraged workers and involuntary part-timers, Canada's "underutilization" rate rises to 10 percent. Nevertheless, since the recession, the quality of work has continued to degrade with most new positions being part-time, temporary or self-employed. This has hit youth (15-24), the elderly (55 and over), women and racialized persons especially hard as long-term unemployment has surged from 15 percent before the downturn to nearly a quarter of jobless people ever since (Grant 2011a/b). ${ }^{20}$ Meanwhile, the most recent report from Statistics Canada shows that Canadians' debt-to-disposable income ratio reached 148.1 percent, which is higher than in the US at 147.2 percent, and a 6.7 percent increase in household obligations from one year ago (Matthieu 2010). With fears of a looming housing bubble in Canada, as the Bank of Montréal (CTV 2011 b) recently reported, estimates suggest that Ontario's housing market is "overvalued" by 10 percent. Given mounting debt-to-financial assets and historic levels of rising bankruptcies, a sudden depreciation in the value of households could have disastrous implications as many households continue to substitute consumption from income with consumption from credit-debt (CGA 2009; MacDonald 2010). This has left policymakers with a Herculean dilemma: restrict spending by raising interest rates and risk prematurely hampering the recovery, or do nothing and risk a cascading future economic crisis? Both options are complex. A sudden shock, such as sharp increases in interest rates, a drop in the value of households and/or deteriorating labour market conditions, could trigger unprecedented personal and corporate bankruptcies, in addition to a banking crisis akin to that which ravaged the US economy and worldwide. With interest rates expected to rise in mid-2011, having already risen three times since June 2010, and declining real wages since the onset of the crisis, the frontier

\footnotetext{
${ }^{19}$ This sentiment was reflected in a recent Canadian Press Harris-Decima survey that found 59 percent of respondents believed Canada was still in a slump (CTV News 2011).

${ }^{20}$ The deteriorating quality of jobs, according to the Ontario Association of Food Banks, is also a significant factor in the growing usage of food banks, which have risen twenty-eight percent since 2008, given mounting food costs, utilities and rents. This has hit single parent households, particularly women, especially hard (Monsebraaten 2011).
} 
separating recovery from relapse is increasingly blurred. With many Canadians borrowing heavily on their personal lines of credit, and with many loans secured against the value of their homes, the Bank of Canada has been hesitant to intervene since other aspects of the economy are so dependent on historically low interest rates. Rather, the Bank of Canada prefers the Department of Finance use its control over mortgage insurance rules, such as maximum amortization periods and minimum down payments standards, to cool the housing market. Both options, however, could be playing with fire, especially considering Europe's growing debt crisis, widening gaps between imports and exports among countries, creeping protectionism amidst specific liberalization measures, and the stark realization that cheap credit will not last forever (Panitch et al. 2010; Callinicos 2010; Georgious 2010; Lapavitsas et al. 2010). Bearing this in mind, Ontario's responses to the Great Recession, like elsewhere, are by no means certain to result in economic recovery or, more importantly, improved living conditions for those hardest hit by the crisis.

\section{Conclusion}

As we have argued throughout, all indications suggest that neoliberal governments will intensify attacks against the working class in the name of stimulating recovery. More specifically, austerity measures will include expenditure restraint and zero-growth measures, privatization of public services and assets, increased confrontations with trade unions over wage restraint, and the undermining of employment standards legislation. Despite the appeal to collectively bear the burden of capitalism's most recent periodic crisis, the disproportionate burden borne by the working class diverges significantly from the government's narrative of "sharing the pain" collectively.

Resistance to austerity, though not yet broad based, is nonetheless emerging. While demonstrations of discontent have manifested unevenly throughout Ontario, new forms of political action, mobilization and organizing have created new openings for voicing opposition to neoliberalism and capitalism. One such re-groupment effort is taking shape in the form of workers' assemblies such as that in Toronto, and emerging in Ottawa and Kingston. Though still in its infancy, the Greater Toronto Workers' Assembly is emphatically anti-capitalist in its approach in seeking to push the strongest elements of the organized labour movement toward class struggles and beyond individual affiliates (Rosenfeld and Fanelli 2010). The assembly process works on a number of levels. It seeks to create a new form of working class organization, bringing together 
FANELLI and THOMAS: Austerity, Competitiveness, and Neoliberalism Redux

working people in unions, in communities, the employed and unemployed and those who are unable to work. Additionally, building on a militant, anti-capitalist class orientation, it aims to address forms of division and segmentation that (neoliberal) capitalism works to conceal and sustain. While the Assembly has thus far surpassed the expectations of many, even a short political memory shows that unexpected shifts in political and economic climate can quickly derail progressive political interventions. Indeed, the current fragmented state of movement politics has left many frustratingly marginalized, unable to reverse or reshape the political agenda. Overcoming it entails developing organizational forms that can actually win substantive changes, within and beyond the workplace, let alone attempt radical undertakings.

Given the significant rise of right-wing populism throughout North America and Europe, it is clear that a third McGuinty term is by no means inevitable. Recent missteps, such as the introduction and subsequent retreat from "eco-fees" that charged levies ranging from a penny to $\$ 6.66$ on products, the $\$ 1$ billion eHealth scandal, a damaging Ombudsman's report criticizing Ontario's troubled Local Health Integration Networks, a large cut in rates for solar energy projects that angered farmers, a 46 percent projected rise in hydro costs over five years, flip-flops on mixed marital arts and online gambling, the removal of the "special diet" food subsidy for those on social assistance, as well as the clear and blatant abuse of police powers during the Toronto G20 summit that witnessed the single largest mass arrest in Canadian history, have tarnished the Liberals' political fortunes. In fact, a September 2010 Toronto Star-Angus Reid survey found that 76 percent of respondents want a new government in power, with a majority of decided voters preferring the Conservatives. That same survey, however, found that nearly 60 percent of respondents were against the privatization of Crown assets (Benzie 2010b). ${ }^{21}$ Nevertheless, Ontario continues to remain one of the hardest hit economies from the financial crisis and the PC's may emerge in this context to re-take provincial Parliament.

In conclusion, the $O B A$ in Ontario was introduced as neoliberal governments across North America and Western Europe championed

\footnotetext{
${ }^{21}$ Similarly, a poll conducted over late January and early February found that only 23 percent of voters believe that McGuinty would make the best premier. The poll places McGuinty nine percentage points behind PC leader Tim Hudak where, compared with a year earlier, the percentage of Ontarians considering him to be the best candidate for premier has risen from 17 to 32 percent (McArthur, 2011).
} 
austerity measures. As Forbes economists Brian Wesbury and Robert Stein (2010) proclaimed, "[t] he time for austerity has come." They could not have been more correct: in 2010, austerity became the policy prescription for North American and Western European economies reeling from the economic crisis. ${ }^{22}$

As governments in Canada follow suit with legislation such as the Ontario $O B A$, those targeted by such measures can gain courage from the growing resistance elsewhere to assert that there is always an alternative. Nonetheless, it is difficult to imagine a new union or social justice movement emerging in Ontario given the historic tensions and isolation of political forces on the Left. Working toward this goal necessarily entails developing our collective capacities as a class, while rooting them in organizational structures capable of transcending the profound pessimism and defeatism borne by recent experiences. Rooting political fightback, as Marx and Engels (2002) once remarked, in the "Lazarus-layers" of the working class means challenging the logic of the market in such a manner that our movements' capacities grow in mutually reinforcing ways, not just as individuals or an isolated union local or community group, but as a class. Of course, rebuilding and transforming formal union structures is a necessary task, as is putting back on the agenda the task of building a mass socialist movement. New organizational experiments such as that in Toronto, Ottawa and Kingston are notable starting points that contain in germ the seed of great promise. We conclude with Engels (1969), who provides a clear reminder of the need for the labour movement, activists and community groups to challenge austerity measures and "proclaim that they, as human beings, shall not be made to bow to social circumstances, but social circumstances ought to yield to them as human beings; because silence on their part would be a recognition of the social conditions, an admission of the right of the bourgeoisie to exploit the workers in good times and let them starve in bad ones."

\footnotetext{
${ }^{22}$ For example, following IMF dictates in order to secure loans to prevent bankruptcy, the Greek, French and British governments passed budgets with severe spending cuts to education, health care, pensions and wage controls (Smith 2010; Chrisafis 2010; Mulholland 2010). These austerity measures appear as the beginning of what could be a major capitalist assault on working class people. While the specificities of European austerity measures vary in each case, in each case they have been met with opposition and growing resistance as the Greek, French and British cases illustrate.
} 
FANELLI and THOMAS: Austerity, Competitiveness, and Neoliberalism Redux

\section{References}

Armstrong, Pat. et al (eds.). 2001. Exposing Privatization: Women and Health Care Reform in Canada. Aurora, ON: Garamond Press.

Andrews, E.L. 2008. “Greenspan Concedes Error on Regulation," The New York Times, 24 October 2008, http://www.nytimes.com/2008/10/24/business/economy/24panel.html.

Benzie, R. 2010a. “Dalton McGuinty confirms 'SuperCorp' being considered.” Toronto Star, 22 June 2010, http://www.thestar.com/news/ontario/article/827135--daltonmcguinty-confirms-supercorp-being-considered.

Benzie, R. 2010b. "McGuinty sinking: Poll shows 76\% want new party in power." Toronto Star, 27 September 2010, http://www.thestar.com/news/ontario/article/867118.

Benzie, R., and P. Moloney. 2010. “McGuinty to Cities: Freeze Wages.” Toronto Star, 26 March 2010, http://www.thestar.com/news/ontario/ontariobudget/article/786092--mcguintyto-cities-freeze-wages.

Benzie, R., and R. Ferguson. 2010. "Arbitrator Rules Against Wage Freeze, Liberals Scoff." Toronto Star, 16 September 2010, http://www.thestar.com/news/canada/article/862403--arbitrator-rules-againstwage-freeze-liberals-scoff.

Bezanson, Kate, and Meg Luxton (eds.). 2006 Social Reproduction: Feminist Political Economy Challenges Neoliberalism. Montréal \& Kingston: McGill-Queen's University Press.

Block, Fred. 2002. "Rethinking Capitalism". In Readings in Economic Sociology, ed. N. Woolsey Biggart, 219-30. Malden, Mass: Blackwell.

Boyd, Susan B. (ed.). 1997. Challenging the Public/Private Divide: Feminism, Law and Public Policy. Toronto: University of Toronto Press.

Braedley, Susan, and Meg Luxton (eds.). 2010. Neoliberalism and Everyday Life. Montréal \& Kingston: McGill-Queen's University Press.

Brenner, N. 1999. "Globalization as Reterritorialization: The Rescaling of Urban Governance in the European Union." Urban Studies 36, no. 3: 431-451.

Brooks, S. 2009. "Canadian Political Culture". In Canadian Politics, eds. J. Bickerton and A.G. Gagnon, 45-70. Toronto: University of Toronto Press.

Brown, L. 2010. "Ruling Gives U of T Profs 4.5\% Over Two Years.” Toronto Star, 12 October 2010, http://www.thestar.com/news/canada/article/874373.

Callinicos, Alex. 2010. Bonfire of Illusions: The Twin Crises of the Liberal World. Cambridge: Polity Press.

CBC News. 2007a. "McGuinty Wins Massive Majority, Tory Loses Seat." CBC.ca, 11 October 2007, http://www.cbc.ca/canada/ontariovotes2007/story/2007/10/10/leaders.html. 
CBC News. 2007b. "Ontario Voter Turnout a Record Low." CBC.ca, 11 October 2007, http://www.cbc.ca/canada/ontariovotes2007/story/2007/10/11/ov-turnout071010.html.

CBC News. 2007c. "Ontario Rejects Electoral Reform in Referendum." CBC.ca, 11 October 2007, http://www.cbc.ca/canada/ontariovotes2007/story/2007/10/10/mmpreferendum.html.

CBC News. 2011. "George Weston to Hike Food Prices." CBC.ca, 03 March 2011, http://www.cbc.ca/news/business/story/2011/03/03/food-inflation-georgeweston.html.

Canadian Federation of Independent Business (CFIB). 2010. "Canadians and small firms oppose forced union dues." News Release, http://www.cfibfcei.ca/english/media_centre/canada/119-labour_policy/2060canadians and small firms oppose forced union dues.html.

Canadian Labour Congress. 2010. Recession Watch Bulletin: Issue 4, http://www.canadianlabour.ca/sites/default/files/pdfs/recession-watch-04winter-2010-en.pdf.

Certified General Accountants Association of Canada. 2009. Where is the Money Now: The State of Canadian Household Debt as Conditions for Economic Recovery Emerge. http://www.cga-canada.org/en-ca/ResearchReports/ca rep 2010-05 debtconsumption.pdf.

Chrisafis, A. 2010. "Nicolas Sarkozy orders break-up of blockades as French protests continue." The Guardian, 21 October 2010.

Colour of Poverty. 2007. "Understanding the Racialization of Poverty in Ontario." http://www.colourofpoverty.ca.

Creese, Gillian. 2007. “Racializing Work/Reproducing White Privilege.” In Work in Tumultuous Times: Critical Perspectives, eds. V. Shalla and W, Clement, 192-226. Montréal \& Kingston: McGill-Queen's Press, 2007.

CTV News. 2011a. "Canadians Still Think Country Is In Recession: Poll." CTV.ca, 04 March 2011, http://www.ctv.ca/CTVNews/Canada/20110304/recession-poll-110304/.

CTV News. 2011b. "Home Prices Approaching Bubble Territory, BMO Says.” CTV.ca, 04 March 2011, http://ottawa.ctv.ca/servlet/an/local/CTVNews/20110304/housingprices-bank-110304/20110304/?hub=0ttawaHome.

Engels, Freidrich. 1969. The Condition of the Working Class in England. http://www.marxists.org/archive/marx/works/1845/condition-workingclass/ch10.htm.

Evans, Bryan. and Greg. Albo. 2010. "Permanent Austerity: The Politics of the Canadian Exit Strategy From Fiscal Stimulus." In Saving Global Capitalism: Interrogating Austerity and Working Class Reponses to Crises, eds. Carlo. Fanelli, C. Hurl, Priscilla. Lefebvre and Gülden Özacan, 7-28. Ottawa: Red Quill Books.

Fanelli, Carlo, and Chris Hurl. 2010. "Janus-Faced Austerity: Strengthening the 'Competitive' Canadian State." In Saving Global Capitalism: Interrogating Austerity 
FANELLI and THOMAS: Austerity, Competitiveness, and Neoliberalism Redux

and Working Class Reponses to Crises, eds. Carlo Fanelli, Chris Hurl, Priscilla Lefebvre and Gülden Özacan, 29-49. Ottawa: Red Quill Books.

Fanelli, Carlo, et al (eds.). 2010. Saving Global Capitalism: Interrogating Austerity and Working Class Responses to Crises. Ottawa: Red Quill Books.

Fenlon, B. 2007. "Referendum on Electoral Reform an 'unmitigated disaster'." The Globe and Mail, 11 October 2007, http://www.theglobeandmail.com/archives/article787661.ece.

Ferguson, R. and R. Benzie. 2010. "'Dalton Days': Premier Likes the Sound of That." Toronto Star, 05 November 2010, http://www.thestar.com/news/ontario/mcguinty/article/721403---dalton-dayspremier-likes-the-sound-of-that.

Fernandez, Lynne. 2009. "We are All Keynesians-Again." In Bankruptcies \& Bailouts, eds. Julie Guard and Wayne Antony, 107-126. Halifax, NS: Fernwood.

Fodor, Matt. 2010. "Fuelling the Tax Revolt: What's Wrong with the NDP's Anti-HST Campaign." The Bullet 410, 03 September 2010, http://www.socialistproject.ca/bullet/410.php.

Galabuzi, Grace-Edward. 2006. Canada's Economic Apartheid: The Social Exclusion of Racialized Groups in the New Century. Toronto: Canadian Scholars Press, 2006.

Gellatly, Mary et al. 2011. "Modernizing' Employment Standards? Administrative Efficiency, Market Regulation, and Precarious Employment in Ontario." Unpublished manuscript, 2011.

Georgious, Christakis. 2010 "The Euro Crisis and the Future of European Integration." International Socialism 128, http://www.isj.org.uk/index.php4?id=682\&issue=128.

Goldfield, Michael and Bryan Palmer. 2007. “Canada's Workers Movement: Uneven Developments." Labour/Le Travail 59: 149-178.

Government of Ontario. 2004. Ontario Budget: The Plan for Change. http://www.fin.gov.on.ca/en/budget/ontariobudgets/2004/pdf/papers all.pdf.

Government of Ontario. 2005. Ontario Budget: Investing In People, Strengthening our Economy. http://www.fin.gov.on.ca/en/budget/ontariobudgets/2005/pdf/papers all.pdf.

Government of Ontario. 2006. Ontario Budget: Building Opportunity. http://www.fin.gov.on.ca/en/budget/ontariobudgets/2006/pdf/statement.pdf.

Government of Ontario. 2007. Ontario Budget: Investing In People and Expanding Opportunity.

http://www.fin.gov.on.ca/en/budget/ontariobudgets/2007/pdf/papers all.pdf.

Government of Ontario. 2008. Ontario Budget: Growing a Stronger Ontario. http://www.fin.gov.on.ca/en/budget/ontariobudgets/2008/pdf/papers all.pdf.

Government of Ontario. 2009. Ontario Budget: Confronting the Challenge, Building our Economic Future.

http://www.fin.gov.on.ca/en/budget/ontariobudgets/2009/papers all.pdf. 
Socialist Studies / Études socialistes 7(1/2) Spring/Fall 2011: 141-170

Government of Ontario. 2010a. Ontario Budget: Open Ontario: Ontario's Plan for Jobs and Growth. http://www.fin.gov.on.ca/en/budget/ontariobudgets/2010/papers all.pdf.

Government of Ontario. 2010b. An Act to Promote Ontario as Open for Business by Amending or Repealing Certain Acts. Schedule 9. Toronto: Government of Ontario.

Grant, T. 2011a. "Labour Market Regains Zip, But Scars Still Linger." The Globe and Mail, 23 February 2011, http://www.theglobeandmail.com/report-onbusiness/economy/jobs/labour-market-regains-zip-but-scarslinger/article1917112/.

Grant, T. 2011b. "Black Canadians Paid On Average Less Than Whites: Study." The Globe and Mail, 04 March 2011, http://www.theglobeandmail.com/report-onbusiness/economy/economy-lab/daily-mix/black-canadians-paid-less-on-averagethan-whites-study/article1929847/.

Harmes, Adam. 2006. "Neoliberalism and Multilevel Governance." Review of International Political Economy, 13, no. 5: 725-749.

Harvey, David. 2006. The Limits to Capital. London \& New York: Verso.

Howlett, K. 2007. "Referendum? Now what referendum would that be?" The Globe and Mail, 24 September 2007, http://www.theglobeandmail.com/archives/article783471.ece.

Hülsemeyer, Axel. 2000. "Changing 'Political Economies of Scale' and Public Sector Adjustment: Insights from Fiscal Federalism." Review of International Political Economy 7, no. 1: 72-100.

Jackson, Andrew. 2009. Work and Labour in Canada: Critical Issues. $2^{\text {nd }}$ Edition. Toronto: Canadian Scholars Press.

Jenson, Jane, Rianne Mahon, and Susan D. Phillips. 2003. "No Minor Matter: The Political Economy of Childcare in Canada." In Changing Canada: Political Economy as Transformation, eds. Wallace Clement and Leah F. Vosko, 135-60. Montréal and Kingston: McGill-Queen's University Press.

Jessop, Bob. 1993. "Towards a Schumpeterian Workfare State? Preliminary Remarks on Post-Fordist Political Economy." Studies in Political Economy 40: 7-39.

Kaplan, G. 2010. "The Hidden History of Bob Rae's Government in Ontario." The Globe and Mail, 08 October 2010, http://www.theglobeandmail.com/news/politics/thehidden-history-of-bob-raes-government-in-ontario/article1749515/.

Keung, N. 2010. "Employment Bill Stymies Complaints Against Employers, Critics Say." Toronto Star, 03 August 2010, http://www.thestar.com/news/ontario/article/843099--employment-billstymies-complaints-against-employers-critics-say.

Kozolanka, Kirsten. 2007. The Power of Persuasion: The Politics of the New Right in Ontario. Montréal : Black Rose Books.

Lapavitsas, C. et al. 2010. Research on Money and Finance: The Eurozone Between Austerity and Default. 
FANELLI and THOMAS: Austerity, Competitiveness, and Neoliberalism Redux

http://www.researchonmoneyandfinance.org/media/reports/RMF-EurozoneAusterity-and-Default.pdf.

Leach, Belinda. 2002. "Class, Discipline and the Politics of Opposition in Ontario." In Culture, Economy, Power: Anthropology as Critique, Anthropology as Praxis, eds. Winnie Lem and Belinda Leach, 191-205. New York: State University of New York Press.

Lewchuk, Wayne. Marlea Clarke and Alice De Wolff. 2011. Working Without Commitments: The Health Effects of Precarious Employment. Montréal and Kingston: McGill-Queen Press.

Loxley, John and Salim Loxley. 2010. Public Service Private Profits: The Political Economy of Public-Private Partnerships in Canada. Halifax, NS: Fernwood Publishing.

Marx, Karl. and Friedrich. Engels. 2002. The Communist Manifesto. London: Penguin Books.

Macdonald, David. 2010. Canada's Housing Bubble: An Accident Waiting to Happen. Canadian Centre for Policy Alternatives. https://s3.amazonaws.com/policyalternatives.ca/sites/default/files/uploads/publ ications/National\%200ffice/2010/08/Canadas Housing Bubble.pdf.

MacDermid, Rob and Greg Albo. 2001. "Divided Province, Growing Protests: Ontario Moves Right." In The Provincial State in Canada: Politics in the Provinces and Territories, eds. Keith Brownslee and Michael Howlett, 163-202. Peterborough, ON: Broadview Press.

Matthieu, E. 2010. Canadian's Spending Far Beyond Means. Toronto Star, 14 December 2010, http://www.thestar.com/article/906396--alarm-raised-as-household-debtspikes.

McArthur, G. 2011. "Ontarians Turning Against McGuinty, Poll Finds." The Globe and Mail, 14 February 2011, http://www.theglobeandmail.com/news/national/ontario/poll-finds-ontariansturning-\%09against-mcguinty/article1905696/?cmpid=rss1.

McBride, Stephen, and John Shields. 1997. Dismantling a Nation: The Transition to Corporate Rule in Canada. Halifax, NS: Fernwood.

McKeen, Wendy and Ann Porter. 2003. "Politics and Transformation: Welfare State Restructuring in Canada." In Changing Canada: Political Economy as Transformation, eds. Wallace Clement and Leah F. Vosko, 109-34. Montréal and Kingston: McGill-Queen's University Press.

Monsebraaten, L. 2011. “400,000 Rely on Food Banks Each Month in Ontario.” Toronto Star, 22 March 2011, http://www.thestar.com/news/article/957658--400-000rely-on-food-banks-each-month-in ontario.

Mulholland, H. 2010. "Tuition fees: government wins narrow victory as protests continue." The Guardian, 09 December 2010.

Naiman, Joanne. 2008. How Societies Work: Class, Power and Change in a Canadian Context. $4^{\text {th }}$ Edition. Black Point, NS: Fernwood. 
Socialist Studies / Études socialistes 7(1/2) Spring/Fall 2011: 141-170

Ontario Ministry of Economic Development and Trade. 2011. Ontario-Quebec Trade and Cooperation Agreement.

http://www.ontariocanada.com/ontcan/1medt/en/about spotlight en.jsp.

Ontario Ministry of Economic Development and Trade. 2010. Open For Business. http://www.ontariocanada.com/ontcan/1medt/en/ofb_main_en.jsp.

Ontario Ministry of Finance. 2011. FAQ: Public Sector Compensation Restraint. http://www.fin.gov.on.ca/en/budget/ontariobudgets/2010/faq_july.html.

Ontario Ministry of Finance. 2010a. Ontario's Long-Term Report on the Economy. http://www.fin.gov.on.ca/en/economy/ltr/2010/ltr2010.pdf.

Ontario Ministry of Finance. 2010b .Backgrounder: Ontario's Tax Plan For Jobs and Growth. http://www.fin.gov.on.ca/en/budget/ontariobudgets/2010/bk tax.pdf.

Ontario Ministry of Labour. 2010a. “Ontario Is Open for Business: McGuinty Government's Proposed Act Will Deliver Results for Business". News Release, 17 May 2010, http://news.ontario.ca/medt/en/2010/05/ontario-is-open-for-business.html.

Ontario Ministry of Labour. 2010b. "Proposed Open for Business Act - What Others Are Saying". News Release, 17 May 2010, http://news.ontario.ca/medt/en/2010/05/proposed-open-for-business-act--what-others-are-saying.html.

Ontario Ministry of Labour. 2010c. "New Legislation Modernizes Ontario's Employment Standards." News Release, 25 October 2010, http://www.labour.gov.on.ca/english/news/bulletin ofba.php.

Ontario Ministry of Labour. , 2010d. "Employment Standards Task Force." News Release, http://www.labour.gov.on.ca/english/news/bulletin ofba.php.

Ontario Public Service Employees Union. n.d. Health Care Division: Ontario Health Coalition. http://www.opseu.org/bps/health/ohc oct0507.htm.

Panitch, Leo and Donald Swartz. 2003. From Consent to Coercion: The Assault on Trade Union Freedoms. 3rd Edition. Toronto: Garamond.

Panitch, Leo, Greg Albo and Vivek Chibber (eds.). 2010. The Crisis This Time, Socialist Register 2011. London: Merlin Press.

Peck, Jamie. Workfare States. 2001. New York \& London: The Guilford Press.

Peck, Jamie. 2005. “Economic Sociologies in Space.” Economic Geography 81, no. 2: 129175.

Peck, Jamie. and Nik Theodore. 2010. "Labor Markets from the Bottom Up." In Handbook of Employment and Society: Working Space, eds. Susan McGrath-Champ, Andrew Herod, and Al Rainnie, 87-105. Northampton, MA: Elgar.

Perelman, Michael. 2006. Railroading Economics: The Creation of the Free Market Mythology. New York: Monthly Review Press.

Quebec-Ontario Trade and Cooperation Agreement. 2009, http://www.mdeie.gouv.qc.ca/fileadmin/sites/internet/documents/publications/ pdf/Exporation/accords/signature quebec ontario trade.pdf. 
FANELLI and THOMAS: Austerity, Competitiveness, and Neoliberalism Redux

Rosenfeld, Herman and Carlo Fanelli. 2010. "A New Kind of Political Organization? The Greater Toronto Workers' Assembly." The Bullet 400, www.socialistproject.ca/bullet/400.php.

Sauvé, Roger. 2010. The Current State of Canadian Family Finances: 2009 Report. Ottawa: VIF.

Sinclair, Scott. 2010. Negotiating From Weakness: Canada-EU Treaty Threatens Canadian Purchasing Policies \& Public Services. Canadian Centre for Policy Alternatives. Ottawa: CCPA.

Smith, H. 2010. "Greek unions vow to step up protests over stringent austerity measures." The Guardian, 24 December 2010.

Standing, Guy. 1999. Global Labour Flexibility: Seeking Distributive Justice. London: MacMillan, 1999.

Statistics Canada. 2011. Latest Release From the Consumer Price Index. http://www.statcan.gc.ca/subjects-sujets/cpi-ipc/cpi-ipc-eng.htm.

Toronto Star. "McGuinty Freezes Minimum Wage." Toronto Star, 11 February 2011, http://www.thestar.com/news/ontario/article/937517--mcguinty-freezesminimum-wage.

TD Economics. 2010. Toronto's Economic Recovery Leaving Many Behind. http://www.td.com/economics/special/sg1010 toronto.pdf.

Teelucksingh, Cheryl, and Grace-Edward Galabuzi. 2005. "Working Precariously: The Impact of Race and Immigrants Status on Employment Opportunities and Outcomes." In Race and Racialization: Essential Readings, eds. Tania Das Gupta et al, 202-208. Toronto: Canadian Scholar's Press.

Thomas, Mark. 2009. Regulating Flexibility: The Political Economy of Employment Standards. Montréal \& Kingston: McGill-Queen's University Press.

Thomas, Mark. 2010. "Neoliberalism, Racialization, and the Regulation of Employment Standards". In Neoliberalism and Everyday Life, eds. S. Braedley and M. Luxton, 6889. Montréal \& Kingston: McGill-Queen's University Press.

Walkom, Thomas. 2002. Rae Days: The Rise and Follies of the NDP. Toronto: Key Porter Books.

Wesbury, Brian S., and Robert Stein. 2010. "Government Austerity: The Good, Bad And Ugly." Forbes.com, 27 July 2010.

Whittington, L. and S. Delacourt. 2011. "Tory Tax Cuts Could Trigger Election.” Toronto Star, 27 January 2011, http://www.thestar.com/news/canada/article/929037-tory-tax-cuts-could-trigger-election.

Workman, Thom. 2009. If Your In My Way, I'm Walking: The Assault on Working People Since 1970. Halifax, NS: Fernwood.

Yalnizyan, Armine. 1998. The Growing Gap: A Report on Growing Inequality Between the Rich and Poor in Canada. Toronto: Centre for Social Justice.

Yalnizyan, Armine. 2010. The Rise of Canada's Richest 1\%. Canadian Centre for Policy Alternatives, 
Socialist Studies / Études socialistes 7(1/2) Spring/Fall 2011: 141-170

http://www.policyalternatives.ca/sites/default/files/uploads/publications/Nation al\%200ffice/2010/12/Richest $\% 201 \% 20$ Percent.pdf.

Zimmerman, Jesse. 2009. "Is the Green Party Progressive or Regressive? YU Free Press, 21 October 2009, http://www.yufreepress.org/?p=119. 